The Birth of Ophthalmology

\title{
THE BIRTH OF OPHTHALMOLOGY AND ITS DEVELOPMENT IN EARLY ARABIC LITERATURE
}

BY

\author{
A. F. MacCallan, C.B.E. \\ LONDON
}

THE papyrus discovered by the archaeologist Ebers, which carries back 3400 years from to-day our knowledge of Egyptian history and of the customs of the ancient Egyptians, indicates that both acute conjunctivitis and trachoma were rife in the country at the time of its inscription. This papyrus was compiled by the medical priests of the Eighteenth Dynasty from one or more books many centuries earlier. According to Dr. Hurry, in his monograph on Imhotep, the Vizier and Physician of the Third Dynasty, portions of the Ebers papyrus date from the First Dynasty. It is a collection of prescriptions, seven hundred in number, in which many diseases of the eye are mentioned.

Epilation forceps have been found in tombs of the New Empire, as well as little pots containing oxides of copper and zinc, and sulphates of lead and antimony. The pigment which these pots contained was used for darkening the edges of the eyelids, as well as for treating conjunctivitis : it has been in use since the earliest times : a wall sculpture at Beni Hassan of about the Nineteenth Century, B.C., shows thirty-seven Bedouin chiefs bringing some of it as a present to the prince of the "nome." Under the name "kohl" it is in use at the present day. Before the Old Empire a green powder, native carbonate of copper, was used as an eye paint, but this practice seems to have become old fashioned even when the Pyramids were being built.

In the Fifth Century, B.C., Hippocrates was born at the Island of Cos, by whose means scientific medicine evolved from its previous superstitious chaos. $\mathrm{He}$ was well acquainted with trichiasis. At the end of the Fourth Century, B.c., ophthalmology was already a recognized speciality at Alexandria, where Herophilus, living in the reign of Ptolemy Soter, wrote a book on the eyes, which unhappily has not been preserved. About this time Euclid studied the first elements of optics at the same place. In the beginning of the Second Century, B.c., Heliodorus practised at Alexandria, and has left a fragment of a work on surgery which describes scalping of the lids for trichiasis, and various remedies for ophthalmia.

At the time of Nero, in the First Century of our era, the famous Celsus lived at Rome : he wrote exactly of trachoma, trichiasis, and operations for cataract. The works of the great Graeco-Roman doctors of the early centuries do not seem to have been concerned very much with ophthalmology, though Cassius Felix in the Fifth 
Century describes "trachomata, id est asperitates palpebrarum." However, they furnished Paul of Aegina, who lived at Alexandria in the Seventh Century, with material for the compilation of three ophthalmological chapters in his book on medicine. He mentions trichiasis for the cure of which he describes the operation in common use by barbers among the fellahin of Egypt until recently. This operation consists in attempting to evert the ingrowing lashes by the removal of a piece of skin from the upper lid; it is effected by including a fold of skin between two pieces of stick or reed which are tied tightly together at their extremities. The skin necroses since its blood supply is cut off and becomes detached, after some days, with the pieces of stick. The trichiasis-entropion is occasionally cured, but always at the expense of a shortened upper lid, and the frequent production of lagophthalmos.

It is said that important books by the surgeons of the Ptolemaic and Roman periods were lost in the conflagrations, which at different epochs destroyed the famous library of Alexandria, but there is little evidence that additional progress was made in ophthalmological knowledge in the six centuries after the time of Celsus.

These notes were compiled from information supplied to the writer by Mr. A. Quibell (MacCallan, Bull. Ophthal. Soc., Egypt, 1920) of the Egyptian Department of Antiquities, and from communications to the Ophthalmological Society of Egypt by Dr. Max Meyerhof, during the years 1908, 1909, and 1910. Important new light on the early period of Arabic medical and ophthalmological literature has been thrown by the latter author in a communication to the last annual meeting of that Society. Besides being an ophthalmic surgeon of distinction, as his numerous and important contributions to German, French, and English literature show, he is an erudite scholar of early Arabic science. Now that Julius Hirschberg is no more, Meyerhof is the greatest authority on Arabic medicine. He has also recently published in Paris a book entitled "Le Monde Islamique," which gives in a short compass most of the knowledge and experience which some of us have acquired with difficulty by living for twenty years in a Moslem country.

In the Bulletin of the Ophthalmological Society of Egypt for 1926, Meyerhof continues his researches, from which the following notes are compiled :

The Arab conquest of Northern Africa and Western Asia was completed about 700 A.D. At this period, the Omayad Khalifs reigned at Damascus. They were patrons of the arts, but scientific knowledge was limited to the Greeks in Egypt and the Syrians in Western Asia. The seventh, Abassid khalif el-Ma'amun (813833 A.D.), was the one who took an active interest in Greek medicine. 
Hellenic science possessed three homes under early Islamic rule, Alexandria in Egypt, Gendêshapûr in Southern Persia, and Marrân in Mesopotamia. In the last-named town were the Sabians, a sect of star-worshippers, translators of Greek scientific books. The Nestorian Christians who were persecuted in the Byzantine

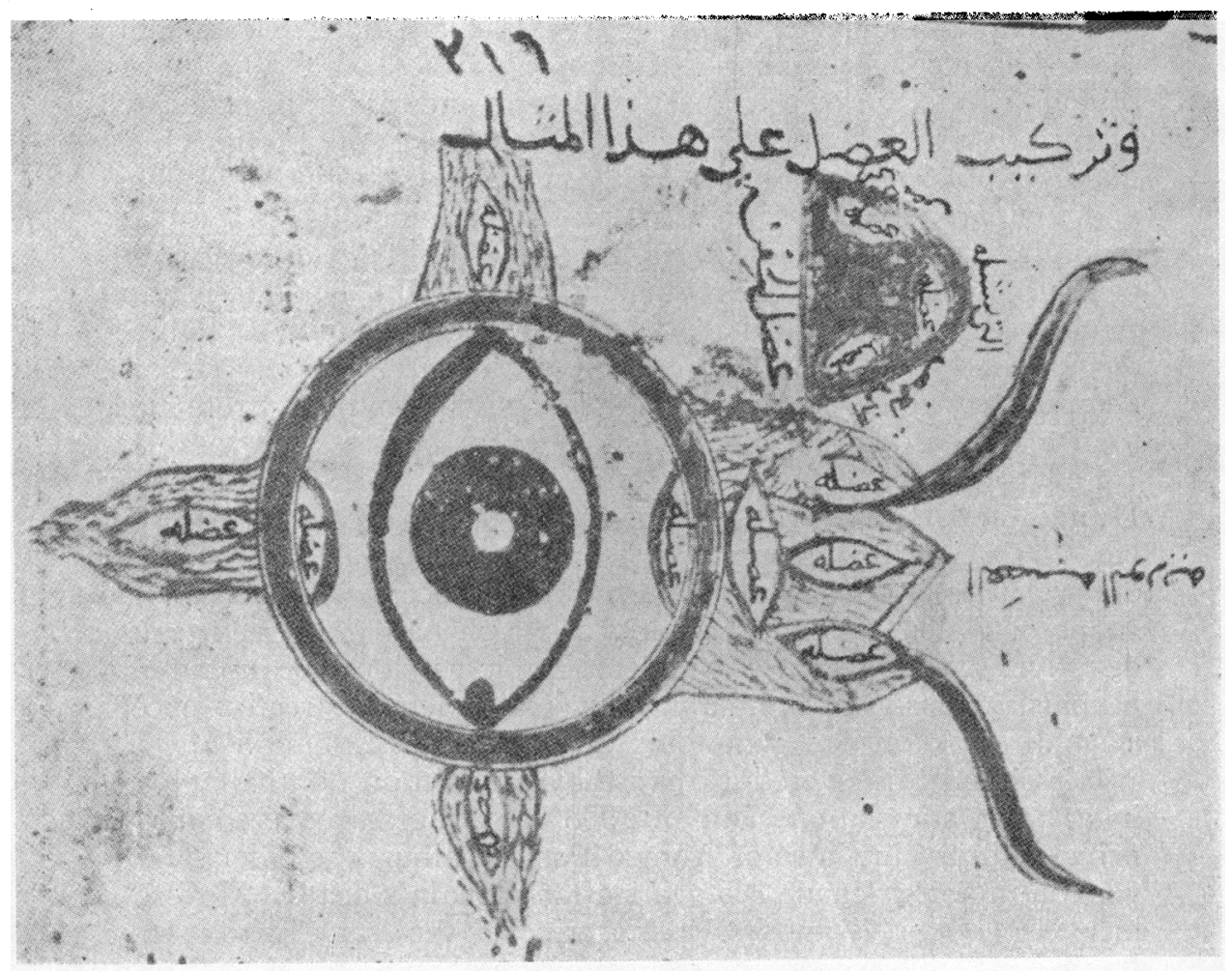

Diagram of the muscles of the eye (Hunain) reproduced from Dr. Max Meyerhof's paper in the Bulletin of the Egyptian Ophthalmological Society for 1926.

Empire, sought refuge in the furthest limits of the Islamic world, carrying with them Greek scientific books. At first they translated them into Syriac, the language spoken throughout Western Asia, but after the end of the seventh century we find more and more Arabic versions of such books. El-Ma'amun sent scholars to Alexandria, Asia Minor, and Byzantium to procure Greek manùscripts for translation. Some of the scholars translated from Greek into Syriac, and others from Syriac into Arabic, as they were unable to translate direct from Greek into Arabic.

Recently Professor Bergstrasser of Munich found a unique manuscript in the Hagia Sophia mosque in Constantinople, giving 
information on all the books of Galen. This is "the Missive of Hunain Ibn Ishaq to Ali Ibn 'Yahya." Hunain was a distinguished Nestorian scholar and physician living in Irak until about 863 A.D. He studied at Baghdad, Gendêshapûr, and Alexandria; he visited Damascus, he accompanied the Khalif El-Ma'anum on his campaign against the Byzantines about 830 A.D., and he was deprived of his library during his imprisonment at Baghdad in 856 A.D. He states that there existed more than 140 medical books of Galen, many of which had been translated into Syriac by himself. His son and his pupils translated many of these into Arabic. He states that some of the Greek manuscripts were defective, and for his translation he collated and compared several copies, his philological methods being quite modern. Besides this work, he translated the philosophical books of Plato and Aristotle, the mathematics of Euclid, Apollonius, and Archimedes, the medical works of Hippocrates, and of Paul of Aegina, and the Bible for the first time into Arabic. He also compiled a large Syriac-Arabic dictionary and himself wrote more than a hundred philosophical and medical books.

Few traces of the enormous amount of translation work done by Hunain and his school are to be found in libraries at the present day. His Syriac versions have nearly all disappeared. However, one very precious Arabic manuscript has been preserved in the shape of Galen's great Anatomy, of which half the Greek text is destroyed and of which a complete Arabic version by Hunain and Hubaish exists. In ophthalmology Galen left no treatise except a small book on the symptoms of eye diseases.

Hirschberg discovered a treatise by Hunain on ophthalmology, in a Latin translation, and in 1908 Meyerhof discovered in the private library in Cairo of Ahmed Pasha Taimur the older Arabic version in a copy made 125 years after Hunain's death. Meyerhof has also obtained another manuscript of the same book from Leningrad. The ten chapters treat of the physiology of the brain, the physiology of vision, the hygiene of the eye, the causes and symptoms of eye diseases, and so on.

Meyerhof obtained from Leningrad in 1925 photographic copies of other early Arabic manuscripts on eye diseases; these are (1) "The Alteration of the Eye," by. Abu Zakariya Yahya ibn. Masawaih (777 A.D. to 857 A.D.). The thirtieth chapter treats of the couching operation for cataract, in which he says : "If the cataract gathered in the eye is accompanied by violent headache it is a hopeless cataract and incurable." This doubtless refers to glaucomatous cataract. The manuscript is written in rather bad Arabic owing to the author's lack of command of that language. (2) "The Anatomy of the Eye, its Formation and the Treatment of its Diseases," by a Nestorian Christian from Northern Syria, Ali 
ibn Ibrahim ibn Bokhtisho, who probably lived about the second half of the tenth century. (3) "The Memorial of the Oculists," by Ali ibn Isa, a Christian oculist of Baghdad, a contemporary in the ninth century of the famous physician Ibn Sina (Avicenna). Meyerhof fully agrees with Hirschberg when he says that no better ophthalmological text-book was written either in the Orient or the Occident until the beginning of the eighteenth century. (4) "Selection in the Treatment of Eye Diseases," by El-Mausili. This is the first Moslem author among the oculists. He lived at Cairo in the early part of the eleventh century. The only complete copy of this work exists in the library of Taimur Pasha in Cairo. It contains a unique account of a new method of operating on soft cataract by sucking out the soft matter through a hollow needle made of gold or brass.

Enough has been said to indicate the important new material which Meyerhof has brought to light. It is of interest to note that the earlier Arabic science was derived from Greek sources and that its practitioners were Christians.

\section{AN OPHTHALMIC RADIATION LAMP: WITH A NOTE ON ITS DIAGNOSTIC AND THERAPEUTIC APPLICATIONS}

THE presentation of this instrument is premature in that its possibilities both in diagnosis and in therapeutics have not yet been thoroughly investigated. Its early notice, however, seems justified if merely to amend a technique in local phototherapy of the eye which I have already described $(1926, a$ and $b$ ) and which I am led to understand is being presently adopted, but which I have now partly abandoned as being inadequate and in some cases potentially dangerous. This technique consisted in localizing the rays from a mercury vapour lamp into a parallel beam by means of a screening apparatus bearing a curved quartz director, and playing them by this means upon the eye. Such a technique is suitable for raying the lids and the conjunctiva, especially in those cases (e.g., trachoma) where the director tip can be inserted into the upper fornix. Incidentally in these, instead of the rod-shaped director originally recommended, an elongated cone-shaped one (K.B.B.) with a broad base tapering to a rounded point at its bent tip will be found more effective. All the rays entering at the base 